•综述・

\title{
我国东北森林土壤动物生态学研究现状与展望
}

\author{
殷秀琴 $1,2,3^{*}$ 陶 岩 ${ }^{2}$ 王海霞 $^{2}$ 马 辰 ${ }^{2}$ 寇新昌 ${ }^{2}$ 许 还 ${ }^{2}$ 崔 东 ${ }^{1}$ \\ 1 (伊犁师范学院生物与地理科学学院, 新疆伊宁 835000) \\ 2 (东北师范大学地理科学学院, 长春 130024) \\ 3 (吉林省动物资源保护与利用重点实验室, 长春 130024)
}

摘要: 土壤动物在生态系统养分循环和能量流动中起到重要的作用。近年来土壤动物生态学研究已成为当前生态 学研究的热点与前沿领域。土壤动物生态学研究在国际上已有 60 多年的历史, 但在我国真正意义上的土壤动物生 态学研究起始于 20 世纪70年代末东北长白山的研究。本文概述了东北森林土壤动物生态学研究的三个阶段, 并重 点从以下方面总结了近 10 年的研究现状与进展: 土壤动物分布格局及多样性、土壤动物对环境因子的响应、土壤 动物在生态系统中的功能作用研究。本文可为进一步拓展东北森林土壤动物生态学研究并为我国其他地区深入开 展土壤动物生态学研究提供参考。未来东北森林土壤动物生态学研究应该关注: 土壤动物与微生物交互作用、土 壤动物对全球变化的响应、地上与地下生态系统的交互作用以及分子生物学技术在土壤生物研究中的应用。

关键词：土壤动物; 分布格局及多样性; 环境因子响应; 功能作用; 东北森林

\section{Forest soil fauna ecology in Northeast China: Review and prospect}

\author{
Xiuqin Yin ${ }^{1,2,3^{*}}$, Yan $\mathrm{Tao}^{2}$, Haixia Wang ${ }^{2}$, Chen $\mathrm{Ma}^{2}$, Xinchang $\mathrm{Kou}^{2}$, Huan $\mathrm{Xu}^{2}$, Dong Cui ${ }^{1}$ \\ 1 College of Biology and Geography, Yili Normal University, Yining, Xinjiang 835000 \\ 2 School of Geographical Sciences, Northeast Normal University, Changchun 130024 \\ 3 Jilin Provincial Key Laboratory of Animal Resource Conservation and Utilization, Changchun 130024
}

\begin{abstract}
Soil fauna have a crucial influence on nutrient cycles and energy flows in ecosystems. In recent years, soil fauna ecology has become a hot topic and frontier in ecology, though it has been studied for more than 60 years at the international level. By contrast, in China, it wasn't until the late 1970s that significant soil fauna ecology studies were performed in the Changbai Mountains. This article summarizes the three periods of soil fauna ecological studies in the forests of northeastern China and reviews the progress made in research in the last decade. Studies from the last decade can be divided into three categories: distribution patterns and diversity, responses to environmental factors, and ecological function. This article provides a reference for further development of soil fauna ecology in the forests of northeastern and other areas of China. Future investigations of soil fauna ecology in the forest of northeastern China should focus on the interaction between soil fauna and microbiota, the responses of soil fauna to global changes, the interaction between aboveground and underground ecosystems, and the application of molecular biology technology in soil biological research.
\end{abstract}

Key words: soil fauna; distribution patterns and diversity; responses to environmental factors; ecological function; forests of northeastern China

土壤动物不仅种类多, 数量大, 而且分布广, 其活动对土壤有机质的形成、土壤理化性质和土壤 肥力的变化以及对生态系统的物质分解和养分循 环都起着重要的作用(Carrillo et al, 2011), 因此土壤
动物是生态系统的重要组成部分。近年来随着地下 生态系统研究的崛起, 土壤动物生态学研究越来越 受到重视(Coyle et al, 2017; Anslan et al, 2018), 已 成为当前生态学研究的热点与前沿领域。土壤动物

收稿日期: 2018-04-08; 接受日期: 2018-07-17 
生态学研究在国际上已有 60 多年的历史, 但我国真 正意义的土壤动物生态学研究起步较晚, 在20世纪 70年代以前几乎无人专门从事土壤动物生态学研 究。1979年中国科学院地理研究所张荣祖领导成立 长白山森林生态定位站土壤动物研究组, 在我国东 北长白山首次开展了土壤动物区系、生态地理研究 (张荣祖等, 1980), 标志着我国土壤动物生态学研究 的起步。之后逐步扩展到对整个东北区、亚热带、 热带、温带其他地区以及寒区、旱区等区域的研究 (Yin et al, 2010)。通过近40年努力, 东北森林土壤动 物生态学研究取得了丰富的资料和可喜的成果。本 文首先对近 40 年东北森林土壤动物生态学研究进 行概述, 然后重点对近 10 年研究的现状与进展进行 总结, 提出未来的研究方向, 为东北森林土壤动物 研究的拓展和我国其他地区深入开展土壤动物生 态学研究提供参考。

\section{东北森林土壤动物生态学研究概}

东北森林土壤动物生态学研究分为三个阶段。

第一阶段: 土壤动物区系调查。由于土壤动物 涉及范围广, 分类鉴定工作困难, 当时国内又缺少 专门的土壤动物分类学家, 因此1984年陈鹏在东北 师范大学创办了全国土壤动物讲习班, 邀请日本土 壤动物专家青木淳一、芝实、石川和男、田中真悟、 石井清等来校讲学并进行了野外考察。掌握了土壤 动物分类鉴定知识之后, 陈鹏领导国内学者在长白 山和吉林省东部及中部开展了土壤动物分类、区系 调查, 取得了东北森林土壤动物生态学研究的基础 资料(陈鹏和张一, 1983; 张一和陈鹏, 1984; 陈鹏和 张一, 1984; 陈鹏等, 1988)。

第二阶段: 土壤动物生态地理研究。1989年陈 鹏等在东北地区进行了土壤动物生态地理调查研 究。初步查清了东北地区土壤动物的种类、数量构 成和生态地理特征, 阐明了土壤动物在不同生态系 统中的结构及与土壤因子的关系, 积累了大量的研 究资料(陈鹏, 1990; 陈鹏和田中真悟 1990), 为东 北森林乃至我国其他地区进一步开展土壤动物生 态学研究奠定了基础(孙帆, 1991; 殷秀琴和张桂荣, 1993; 殷秀琴和赵红音, 1994)。

第三阶段: 土壤动物生态系统研究。在上述工 作的基础上, 重点研究土壤动物在生态系统中的功 能作用。1995年以来, 以小兴安岭凉水自然保护区、
张广才岭帽儿山为研究区, 开展了土壤动物及其功 能作用的研究(张雪萍等, 1996; 仲伟彦等, 1999; 殷 秀琴等, 2002)。特别是近10年来, 除了进一步加强 土壤动物群落特征、生态分布、多样性及与环境因 子关系等研究外, 还以小兴安岭、长白山等地为研 究区, 开展了土壤动物在东北森林生态系统养分循 环和能量流动中的作用(殷秀琴等, 2007a, b, c; Dong et al, 2007; Song et al, 2008)、长白山垂直带土 壤动物多样性及其在调落物分解和元素释放中的 贡献(Jiang et al, 2013; Li et al, 2014; Wang et al, 2015)、长白山地土壤动物分布格局及其对环境变化 的响应(殷秀琴等, 2016; 韩慧莹等, 2017; 李红月等, 2017)、大兴安岭不同冻土带土壤动物等的研究 (Gao et al, 2012; 张武等, 2013); 以及对土壤螨类 (Zhang LM et al, 2015)、土壤跳虫(Sun et al, 2013; 许还等, 2017)、土壤线虫(Zhang et al, 2015)、N沉降 对温带森林土壤线虫群落的影响等研究(程云云等, 2018)。上述研究积累了大量的成果, 东北森林土壤 动物生态学研究得到了长足的发展。下文概括总结 近10年来的重要研究进展。

\section{东北森林土壤动物分布格局及}

\section{1 土壤动物群落水平分布格局}

由于土壤动物活动范围小、迁移能力弱等特点, 不同季节水热条件变化都会影响土壤动物的水平 分布, 同时由于诸多生态系统的环境条件差异较大, 对土壤动物群落组成具有重要的影响, 进而会产生 群落空间格局的变化(Yin et al, 2010)。如在长白山 地的玄武岩台地、花岗岩低山和花岗岩丘陵次生林 的研究(寇新昌和殷秀琴, 2017)表明, 土壤动物群落 组成存在一定差异。春夏秋季节, 大型和中小型土 壤动物水平分布格局在不同地貌类型中有明显差 异, 表现为大型土壤动物水平分布格局差异性小, 中小型土壤动物水平分布格局差异性大。丘陵区不 同生境土壤动物群落的水平分布呈现明显差异, 采 伐迹地中小型土壤动物个体密度与耕地存在明显 差异(李红月等, 2017)。

不同纬度、不同植被类型，甚至同一植被类型， 由于分布的地理纬度、海拔及植物群落组成不同, 土壤动物的水平分布格局也不尽相同。大兴安岭西 坡的个体数、类群数和稀有类群数均高于东坡。处 于高纬度的东坡塔河和西坡满归的土壤动物个体 
密度最小(张雪萍等, 2007)。殷秀琴等(2011)在长白 山红松阔叶混交林分布的上缘、典型分布区和分布 下缘的研究发现, 土壤动物类群数在分布下缘 > 典型分布区 $>$ 分布上缘。3个分布区土壤动物群落 组成存在差异, 其中典型分布区土壤动物群落组成 均匀。小兴安岭中小型土壤动物水平分布特征表现 为, 生境不同土壤动物群落组成和数量不同。10个 生境个体数最多的是人工云冷杉(Picea koraiensis 和Abies nephrolepis)林, 类群最多的是赤杨(Alnus hirsuta) 林, 个体数和类群最少的均为林间草甸, 体 现了小兴安岭森林生态系统的中小型土壤动物的 水平分布格局(辛未冬等, 2009)。

\section{2 土壤动物群落垂直分布格局}

随着海拔的变化, 长白山不同垂直带的环境条 件都发生了相应的改变, 从而影响着土壤动物群落 的垂直分布格局。4个垂直带土壤动物群落组成存 在差异。随着海拔升高, 土壤动物个体数、类群数 和多样性均呈减少趋势。低海拔的针阔叶混交林带 和针叶林带土壤动物数量在春夏最高, 高海拔的岳 桦林带(Betula ermanii)和苔原带土壤动物数量增加 受到低气温的限制, 并且高海拔的岳桦林带和苔原 带大型土壤动物优势类群非常突出(Yin et al, 2017), 中小型土壤动物以螨类和弹尾类为主(Jiang et al, 2015)。

线蚓类、弹尾类、线虫类是土壤动物的重要类 群, 在生态系统中起着关键作用, 它们对森林类型 和海拔高度的响应至关重要。Lian等(2011)研究了 长白山不同森林类型中线蚓多样性及环境变量对 动物群落分布格局的影响发现，5种森林类型中线 蚓丰富度无显著差异, 但在主要属中存在显著差 异。在高海拔地段调落物层的厚度与动物密度密切 相关。由于土层环境条件相对稳定, 调落物层的温 度和水分变幅明显, 因此土壤层弹尾类密度随海拔 升高呈上升趋势, 而调落物层则相反(李佳艺, 2017) ${ }^{1}$ 。土壤线虫丰度和多样性在海拔梯度上也存 在显著差异, 其中在 $760 \mathrm{~m}$ 的针阔混交林中土壤线 虫的多样性最高, 森林类型差异可以通过典型的线 虫属来体现(Zhang et al, 2012)。不同森林类型及不 同土壤深度的食真菌线虫种类丰富度高于其他类 群(Tong et al, 2010)。

(1) 李佳艺 (2017) 长白山森林生态系统自然垂直带弹尾虫群落的变化 研究. 硕士学位论文, 内蒙古师范大学, 呼和浩特.

\section{3 土壤动物群落多样性的时间动态}

土壤动物多样性是土壤动物生态学关注的主 要问题之一, 而在森林生态系统土壤动物多样性方 面, 国外学者多针对土壤动物的某一类群进行研究, 例如螨类、线虫类、弹尾类、蚯蚓等。我国及东北 区主要侧重土壤动物总体类群的研究。地貌类型、 季节及植被类型等的不同，都会对土壤动物多样性 产生影响。长白山玄武岩台地大型土壤动物多样性 在春季次生针阔混交林最高，夏季和秋季原始针阔 混交林最高; 中小型土壤动物多样性在春、秋季原 始针阔混交林最高，夏季次生针阔混交林最高(殷 秀琴等，2016)。在丘陵区，同一季节土壤动物丰富 度和多样性指数在不同生境差异显著, 多样性以灌 木林最高(李红月等, 2017)。林地采伐后形成采伐迹 地，植物种类组成、数量及群落环境都发生了相应 的变化, 植被处于逐渐恢复阶段, 土壤动物群落变 化因采伐前林型不同而存在差异(单昱等, 2014)。

不同演替阶段次生林中土壤线虫属数和 Shannon-Wiener指数基本上随着林龄增加而增加; 在各演替阶段和不同土壤深度，丰富度最大的均是 食细菌线虫(佟富春等, 2009)。而Zhang等(2015)对长 白山3 个不同年龄森林土壤线虫群落研究发现，土 壤线虫的总丰度和多样性并没有随着森林年龄的 增加而持续增加。

大兴安岭地处寒温带, 也是我国重要的林区。 大兴安岭 7 个森林群落土壤动物最大类群为线蚓和 蚯蚓。土壤动物的个体数量、种类及多样性具有明 显的季节变化(张雪萍等, 2008), 不同冻土带大型土 壤动物多样性基本上是由连续多年冻土带向岛状 冻土带逐渐降低(张武和张雪萍, 2013)。

\section{3 东北森林土壤动物对环境因子的}

\section{1 土壤理化性质对土壤动物的影响}

土壤动物对土壤环境的变化非常敏感, 不同的 土壤水分、温度、 $\mathrm{pH}$ 、有机质、 $\mathrm{C} 、 \mathrm{~N}$ 和 $\mathrm{C} / \mathrm{N}$ 等的变 化都会对土壤动物的数量、种类及生物量等产生显 著的影响。刘继亮等(2008)从小尺度上探讨了大型 土壤动物群落与土壤因子的关系。通过对左家自然 保护区阴坡和阳坡的坡谷、坡麓、坡中和坡顶的研 究发现，除植被因子外，土壤的有机质、含水率、 $\mathrm{pH}$ 、全 $\mathrm{N}$ 、全 $\mathrm{P}$ 和土壤温度是影响大型土壤动物分 布的重要因子。对长白山玄武岩台地 4 个生境的研 
究表明, 土壤动物随土层深度的增加而降低的主要 影响因子是土壤温度、速效 $\mathrm{P} 、$ 有机质和土壤湿度(殷 秀琴等, 2016)。丘陵区不同土地利用方式也影响土 壤动物群落的分布, 土壤 $\mathrm{pH}$ 、有机质、有效 $\mathrm{P}$ 和速 效 $\mathrm{N}$ 是影响土壤动物群落分布的主导因子(李红月 等, 2017)。长白山地低山区大型土壤动物的密度、 类群数与土壤温度具有显著正相关关系, 中小型土 壤动物的密度、类群数对土壤湿度具有显著正向响 应。大型土壤动物的密度对速效养分的响应程度较 高, 而中小型土壤动物的类群数对速效养分的响应 程度较高(韩慧莹等, 2017)。

环境中的诸多生态因子对生物都会产生影响, 但在不同地区、不同生境对生物起作用的生态因子 并非等同, 常常是一种或几种生态因子起主要作 用。对帽儿山落叶林的研究表明, 土壤有机质、含 水率等对土壤跳虫群落具有显著的影响(高梅香等, 2014); 土壤 $\mathrm{pH}$ 在螨种调控中起着重要作用(Zhang LM et al, 2015)。而对长白山各林型的研究表明, 裸 肉足虫群落的组成和结构主要受土壤 $\mathrm{pH} 、 \mathrm{NH}_{4}^{+}$以及 C/N的影响(刘芳等, 2014)。

\section{2 土壤动物对 $\mathrm{N}$ 沉降的响应}

近年来, 关于模拟 $\mathrm{N}$ 沉降对土壤线虫群落影响 的研究已引起广泛关注, $\mathrm{N}$ 沉降引起的环境变化影 响着森林生态系统土壤生态过程, 进而影响生态系 统的物质循环和能量流动过程。 $\mathrm{N}$ 添加处理可以减 少有机层总线虫丰度, 而在矿物层中则发现相反的 趋势(Sun et al, 2013)。增加N沉积会改变土壤有机碳 分解, 对陆地生态系统土壤有机碳存储会产生影响 (Wang et al, 2017)。N沉降可显著影响土壤线虫群落 组成和多样性, 但是多数研究集中在无机氮沉降的 影响, 而不同氮素形态对土壤线虫群落的影响还不 清楚。程云云等(2018)在帽儿山的研究发现, 与无机 氮相比, 混合氮处理显著降低了食真菌线虫数量, 有机氮处理显著增加了捕食杂食性线虫数量。

\section{4 东北森林土壤动物在生态系统中的功能作用}

\section{1 土壤动物对调落物分解的贡献}

森林调落物分解是养分归还土壤的一种重要 形式, 是森林生态系统物质循环的重要环节。影响 调落物分解的主要因子有调落物性质、分解者和环 境因子。土壤动物对调落物分解起着不可替代的作 用。然而对土壤动物的了解仍然是当今森林生态系
统研究的薄弱环节。通过对长白山红松阔叶混交林 的红松(Pinus koraiensis)、水曲柳(Fraxinus mandshurica)、紫椴(Tilia amurensisa)和色木槭(Acer mono) 调落物研究发现，在调落物分解过程中，不同物种 调落物中土壤动物类群和个体密度存在显著的差 异。水曲柳调落物中土壤动物类群和个体密度最高, 红松则最低。土壤动物可以促进调落物的分解并提 高凋落物的分解速率。可见调落物的性质是影响分 解速率和土壤动物群落组成及作用的重要因素 (Jiang et al, 2013)。

对长白山岳桦林的研究发现, 在调落物分解初 期土壤动物没有促进分解, 12 个月时土壤动物分解 作用明显。经过 1 年, 土壤动物对星叶蟹甲草 (Parasenecio komarovianus)调落物分解贡献率最低 (7.02\%), 对牛皮杜鹃(Rhododendron aureum)贡献率 最高(25.26\%)。分解8个月和10个月时, 岳桦 + 星 叶蟹甲草混合调落物中土壤动物的个体数、类群数 显著高于单种调落物。随着调落物分解时间的延长, 土壤动物对调落物分解的作用逐渐加强 ( $\mathrm{Li}$ et al, 2014)。对长白山针叶林研究发现, 中小型土壤动物 的群落组成在臭冷杉(Abies nephrolepis)和鱼鳞云杉 (Picea jezoensis)调落物中存在明显差异。初期土壤 动物对调落物分解作用较弱, 分解 10 个月后促进作 用明显加强。海拔、调落物处理和分解时间对中小 型土壤动物群落组成有明显影响。上部针叶林中小 型土壤动物对调落物分解贡献率(分别为 $26.3 \%$ 和 19.44\%)高于下部针叶林(分别为15.52\%和 $16.02 \%$ ) (Wang et al, 2015)。

微生物是土壤动物的营养来源, 土壤动物在生 态系统中, 通过消化和粉碎落叶刺激微生物参与调 落物分解。在大兴安岭北部，通过对针阔混交林有 效微生物处理, 加速了针叶调落物的分解, 表明添 加微生物可以帮助土壤动物个体生长, 进而促使调 落物分解(Gao et al, 2012)。大连国家森林公园土壤 线虫对调落物分解的贡献率年均为 $24 \%$, 可见，土 壤线虫对城市森林调落物分解速率具有明显的促 进作用(王璐等, 2015)。

\section{2 土壤动物对凋落物分解中元素释放的贡献}

在调落物的分解过程中，营养元素的释放保证 了植物再生长养分的可利用性。土壤动物在促进森 林生态系统物质循环和养分平衡方面具有重要的 作用。Li等(2015)对长白山岳华林土壤动物研究发 
现, 在调落物分解过程中, 单种和混合种均表现出 $C$ 的释放。在两种网孔处理中, 岳桦、牛皮杜鹃和岳 桦+牛皮杜鹃混合调落物在分解 6 个月时表现出 $\mathrm{N}$ 的 积累，土壤动物没有促进调落物 $\mathrm{C}$ 的释放。分解 24 个月时，除了 $\mathrm{C} / \mathrm{N}$ 高的牛皮杜鹃调落物外，土壤动 物促进了所有调落物 $\mathrm{C}$ 和 $\mathrm{N}$ 的释放。可见土壤动物对 调落物分解速率和养分释放作用的大小取决于凋 落物的组成成分。

对长白山针叶林研究发现, 两种网孔调落物干 重和养分残留率在不同分解时期存在差异。经过2 年的分解，两种网孔调落物中，臭冷杉的 N、P、Ca、 $\mathrm{Mg}$ 和 $\mathrm{Mn}$ 残留率均显著低于鱼鳞云杉, 而干重和C 的残留率没有显著差异。网袋内中小型土壤动物螨 类和弹尾类为优势类群, 它们对调落物养分释放有 显著的促进作用(王振海, 2016)。对长白山针阔混交 林研究发现, 土壤动物对 $\mathrm{C} 、 \mathrm{~N} 、 \mathrm{Ca}$ 和 $\mathrm{Mg}$ 元素释放 都具有明显的促进作用, 而对 $\mathrm{P}$ 和 $\mathrm{Mn}$ 元素释放的影 响相对微弱; 不同土壤动物类群对元素释放率的作 用大小依调落物处理不同而存在差异(蒋云峰, 2013)。土壤线虫对元素释放率不同, 其中对N元素 释放率较大, 对 $\mathrm{K}$ 元素释放率最小。土壤线虫对城 市森林调落物主要元素释放有显著影响, 其中对 $\mathrm{N}$ 元素释放具有明显的促进作用(王璐等, 2015)。

\section{3 森林系统营养元素关系及土壤动物的作用}

调落物-土壤动物-土壤系统是生态系统物质 循环的重要部分, 调落物是土壤动物的食物和能量 来源。殷秀琴等(2007a)对小兴安岭凉水6个林型的 调落叶、土壤动物和土壤营养元素的关系研究发现, 蚯蚓、线蚓、蜈蚣和其他类群体内的营养元素中, $K$ 、 $\mathrm{Ca} 、 \mathrm{Mg} 、 \mathrm{Fe}$ 对土壤动物生长发育影响较大。调落 叶和土壤中的营养元素含量对土壤动物密度、种类 及生物量有重要影响, 同样, 土壤动物对调落物、 土壤中的营养元素也产生影响, 土壤动物种类组 成、密度和生物量影响土壤食物网结构, 进而影响 营养元素在调落物和土壤间的周转率。殷秀琴等 (2006)对吉林省左家不同地形部位研究发现, 土壤 动物体内 $\mathrm{N} 、 \mathrm{P} 、 \mathrm{Ca}$ 含量明显高于调落物和土壤, 土 壤中 $\mathrm{K} 、 \mathrm{Mg} 、 \mathrm{Fe}$ 元素含量则高于土壤动物和凋落物; 调落物和土壤动物体内元素含量的变化对土壤中 元素含量变化的贡献率较大。

对小兴安岭凉水红松阔叶混交林的紫椴、水曲 柳、枫华(Betula costata)、色木棫和红松及混合调落
叶的研究发现, 不同调落叶在分解过程中元素损失 量差异不显著; 虾蚓、蜈蚣和马陆体内营养元素含 量差别较大; 各类土壤动物和土壤中主要营养元素 含量与凋落叶中变化趋势不同。 $\mathrm{N}$ 和 $\mathrm{P}$ 表现出一定的 富集，而 $\mathrm{K}$ 的富集不明显。土壤动物可通过新陈代 谢活动加速调落物一土壤动物一土壤系统中营养元 素的循环(殷秀琴等, 2007b)。马陆对土壤中 $\mathrm{Ca}$ 和 $\mathrm{Mg}$ 强烈富集，蚳蚓对Fe有一定的富集(Song et al, 2008)。不同土壤动物对不同元素的富集程度不同。 土壤动物体内微量元素含量与环境、调落物分解、 土壤动物食性及对微量元素的选择性吸收和富集 作用等有关(殷秀琴等, 2007c)。

\section{东北森林土壤动物生态学研究展}

近10年来, 我国东北森林土壤动物生态学研究 在土壤动物分布格局及多样性、土壤动物对环境因 子的响应、土壤动物在生态系统中的功能作用研究 等方面取得了长足的进展。未来我国东北森林土壤 动物生态学研究还应关注以下几个方面:

(1)土壤动物与微生物交互作用。明确土壤动物 和微生物在物质分解、养分循环等生态系统功能中 的协同作用与功能差异，以及两者之间的相互作用， 揭示并区分土壤动物与微生物在生态系统过程中 作用的阶段性和贡献率。

(2)土壤动物对全球变化的响应。从多角度、多 尺度研究全球变化对土壤动物群落结构、多样性、 功能等方面的影响, 深入研究土壤动物在维持生物 地球化学循环和生态系统功能稳定中的作用机制, 尤其是全球变暖、 $\mathrm{N}$ 沉降和 $\mathrm{CO}_{2}$ 增加、降水格局变 化等典型全球变化因子对土壤动物的影响, 揭示土 壤动物对全球变化的响应机制。

(3)地上与地下生态系统的相互作用。主要包括 地上生态系统变化对土壤生物(土壤动物、微生物) 产生的直接和间接影响, 以及土壤生物对地上-地 下生态系统变化的响应。揭示土壤生物在土壤-植 被系统中的地位与作用, 特别是由于植物入侵、群 落演替、土地利用类型改变等因素引起的地上-地 下生态系统的变化。

(4)分子生物学技术在土壤生物研究中的应用。 利用DNA、RNA、分子标记、序列分析以及同位素 示踪等先进技术，提高土壤动物物种鉴定精确程度， 准确判断土壤动物在不同生境中的群落组成、多样 
性及功能特征，追踪土壤动物在环境胁迫下的运动 迁移过程，明确土壤动物在食物网中的营养级结构, 并能通过基因或蛋白质的改变, 深入揭示土壤动物 对环境变化的适应过程和指示意义。

\section{参考文献}

Anslan S, Bahram M, Tedersoo L (2018) Seasonal and annual variation in fungal communities associated with epigeic springtails (Collembola spp.) in boreal forests. Soil Biology \& Biochemistry, 116, 245-252.

Carrillo Y, Ball BA, Bradford MA, Jordan CF, Molina M (2011) Soil fauna alter the effects of litter composition on nitrogen cycling in a mineral soil. Soil Biology \& Biochemistry, 43, 1440-1449.

Chen P (1990) Series studies on soil animals in the eastern mountains of Jilin Province. Journal of Northeast Normal University, (2), 77-88. (in Chinese with English abstract) [陈鹏 (1990) 吉林省东部山地土壤动物系列研究. 东北 师大学报自然科学版, (2), 77-88.]

Chen P, Shin GTK (1990) Primary investigation on soil Collembola in Jingyuetan region of Changchun. Acta Entomologica Sinica, 33, 219-226. (in Chinese with English abstract) [陈鹏, 田中真悟 (1990) 长春净月潭地区土壤跳 虫的生态分布. 昆虫学报, 33, 219-226.]

Chen P, Wen ZG, Aoki J, Shiba M, Ishiawa K (1988) Investigation on soil acarid in Jingyuetan area Changchun. Acta Zoologica Sinica, 34, 282-293. (in Chinese with English abstract) [陈鹏, 文在根, 青木淳一, 芝实, 石川和男 (1988) 长春净月潭地区土壤螨类的调查研究. 动物学报, 34 , 282-293.]

Chen P, Zhang Y (1983) Periglacial environment and soil fauna on the northern slope of Changbai Mountain. Scientia Geographica Sinica, 8, 133-140. (in Chinese with English abstract) [陈鹏, 张一 (1983) 长白山北坡冰缘环境与土 壤动物. 地理科学, 8, 133-140.]

Chen P, Zhang Y (1984) The population of soil animals and its dynamics under the broadleaved-Korean pine forest of Changbai Mountain. Research of Forest Ecosystem, 4, 149-158. (in Chinese with English abstract) [陈鹏, 张一 (1984) 长白山红松阔叶林下土壤动物群及其在时间上的 变化. 森林生态系统研究, 4, 149-158.]

Cheng YY, Sun T, Wang QK, Liang WJ, Zhang XK (2018) Effects of simulated nitrogen deposition on temperate forest soil nematode communities and their metabolic footprints. Acta Ecologica Sinica, 38, 475-484. (in Chinese with English abstract) [程云云, 孙涛, 王清奎, 梁文举, 张晓珂 (2018) 模拟氮沉降对温带森林土壤线虫群落组成和代谢 足迹的影响. 生态学报, 38, 475-484.]

Coyle DR, Nagendra UJ, Taylor MK, David R, Campbell JH, Cunard CE, Joslin AH, Mundepi A, Phillips CA, Callaham MA Jr (2017) Soil fauna responses to natural disturbances, invasive species, and global climate change: Current state of the science and a call to action. Soil Biology \& Biochemistry, 110, 116-133.

Dong WH, Yin XQ (2007) Transformation of carbon and nitrogen by earthworms in decomposition processes of broad-leaved litters. Chinese Geographical Science, 17, 166-172

Gao MX, He P, Sun X, Zhang XP, Wu DH (2014) Relative contributions of environmental filtering, biotic interactions and dispersal limitation in a soil collembolan community from a temperate deciduous forest in the Maoer Mountains. Chinese Science Bulletin, 59, 2426-2438. (in Chinese with English abstract) [高梅香, 何萍, 孙新, 张雪萍, 吴东辉 (2014) 环境篎选、扩散限制和生物间相互作用在温带落 叶阔叶林土壤跳虫群落构建中的作用. 科学通报, 59, 2426-2438.]

Gao MX, Li JK, Zhang XP (2012) Responses of soil fauna structure and leaf litter decomposition to effective microorganism treatments in Da Hinggan Mountains, China. Chinese Geographical Science, 22, 647-658.

Han HY, Yin XQ, Kou XC (2017) Community characteristics of soil fauna in the low-mountain of the Changbai Mountains and its respond to the change of environmental factors. Acta Ecologica Sinica, 37, 2197-2205. (in Chinese with English abstract) [韩慧莹, 殷秀琴, 寇新昌 (2017) 长白 山地低山区土壤动物群落特征及其对环境因子变化的响 应. 生态学报, 37, 2197-2205.]

Jiang YF (2013) Litter Decomposition and Functional Role of Soil Fauna in Decomposition in a Pinus koraiensis Mixed Broad-leaved Forest of Changbai Mountains. PhD dissertation, Northeast Normal University, Changchun. (in Chinese with English abstract) [蒋云峰 (2013) 长白山针阔混交林 主要调落物分解及土壤动物的作用. 博士学位论文, 东 北师范大学, 长春.]

Jiang YF, Yin XQ, Wang FB (2013) The influence of litter mixing on decomposition and soil fauna assemblages in a Pinus koraiensis mixed broad-leaved forest of the Changbai Mountains, China. European Journal of Soil Biology, 55, 28-39.

Jiang YF, Yin XQ, Wang FB (2015) Composition and spatial distribution of soil mesofauna along an elevation gradient on the north slope of the Changbai Mountains, China. Pedosphere, 25, 811-824.

Kou XC, Yin XQ (2017) Soil fauna community diversity and distribution characteristics in different secondary forest of Changbai Mountains. Mountain Research, 35, 429-436. (in Chinese with English abstract) [寇新昌，殷秀琴 (2017) 长 白山地不同次生林土壤动物群落多样性特征及其分布格 局. 山地学报, 35, 429-436.]

Li HY, Yin XQ, Ma C, Guo YM (2017) Ecological distribution of soil fauna communities in hilly regions of the Changbai Mountains relative to land use. Acta Pedologica Sinica, 54, 1018-1028. (in Chinese with English abstract) [李红月, 殷 
秀琴, 马辰, 郭玉梅 (2017) 长白山地丘陵区不同土地利 用方式土壤动物群落生态分布特征. 土壤学报, 54, 1018-1028.]

Li XQ, Yin XQ, Wang ZH, Fan WH (2014) Interaction between decomposing litter and soil fauna of the Betula ermanii forest floor of the Changbai Mountains, China. Canadian Journal of Forest Research, 44, 1507-1514.

Li XQ, Yin XQ, Wang ZH, Fan WH (2015) Litter mass loss and nutrient release influenced by soil fauna of Betula ermanii forest floor of the Changbai Mountains, China. Applied Soil Ecology, 95, 15-22.

Lian H, Chen J, Xiong J, Jiang XM, Xie ZC (2011) Structure and distribution of enchytraeid communities from Mountain Changbaishan in China, with emphasis on the influence of environmental variables. European Journal of Soil Biology, 7, 223-229.

Liu F, Li Q, Shen CC, Chu HY, Liang WJ (2014) Distribution of gymnamoebae communities along an elevational gradient in Changbai Mountains. Biodiversity Science, 22, 608-617. (in Chinese with English abstract) [刘芳, 李琪, 申聪聪, 褚海燕, 梁文举 (2014) 长白山不同海拔梯度裸肉足虫 群落分布特征. 生物多样性, 22, 608-617.]

Liu JL, Yin XQ, Qiu LL (2008) Large-sized soil fauna and soil factors in Zuojia Nature Reserve. Acta Pedologica Sinica, 45, 130-136. (in Chinese with English abstract) [刘继亮, 殷秀琴, 邱丽丽 (2008) 左家自然保护区大型土壤动物 与土壤因子关系研究. 土壤学报, 45, 130-136.]

Shan Y, Jiang YF, Yin XQ, Wang ZH (2014) Characteristics of soil fauna community of clear-cutting forestland in Zuojia Nature Reserve. Chinese Journal of Applied and Environmental Biology, 20, 508-515. (in Chinese with English abstract) [单昱, 蒋云峰, 殷秀琴, 王振海 (2014) 左家自然 保护区采伐迹地土壤动物群落特征. 应用与环境生物学 报, 20, 508-515.]

Song B, Yin XQ, Zhang Y, Dong WH (2008) Dynamics and relationship of $\mathrm{Ca}, \mathrm{Mg}$, Fe in litter, soil fauna and soil in Pinus koraiensis-broadleaf mixed forest. Chinese Geographical Science, 18, 284-290.

Sun F (1991) Study on ecological geography of soil animals in Northeast China. Advances in Earth Science, 6, 87-88. (in Chinese with English abstract) [孙帆 (1991) 东北地区土 壤动物生态地理研究. 地球科学进展, 6, 87-88.]

Sun XM, Zhang XK, Zhang SX, Dai GH, Han SJ, Liang WJ (2013) Soil nematode responses to increases in nitrogen deposition and precipitation in a temperate forest. PLoS ONE, 8, e82468.

Tong FC, Xiao YH, Wang QL (2009) Effects of succession process of secondary forestry on characteristics of soil nematode communities in Changbai Mountain. Journal of South China Agricultural University, 30, 63-68. (in Chinese with English abstract) [佟富春, 肖以华, 王庆礼 (2009) 长白山次生林演替过程中土壤线虫群落结构特点. 华南 农业大学学报, 30, 63-68.]
Tong FC, Xiao YH, Wang QL (2010) Soil nematode community structure on the northern slope of Changbai Mountain, Northeast China. Journal of Forestry Research, 21, 93-98.

Wang L, Zhang WD, Wang XF, Li WL (2015) Effects of soil nematode communities on litter decomposition in urban forest of Dalian. Chinese Journal of Applied and Environmental Biology, 21, 933-939. (in Chinese with English abstract) [王璐, 张伟东, 王雪峰, 李伟丽 (2015) 土壤线虫 群落对大连城市森林调落物分解的影响. 应用与环境生 物学报, 21, 933-939.]

Wang QK, Tian P, Liu S, Liu SG, Sun T (2017) Inhibition effects of $\mathrm{N}$ deposition on soil organic carbon decomposition was mediated by $\mathrm{N}$ types and soil nematode in a temperate forest. Applied Soil Ecology, 120, 105-110.

Wang ZH (2016) Litter Decomposition and the Effects of Soil Fauna on the Litter Decomposition and Nutrient Release in the Coniferous Forest of the Changbai Mountains. PhD dissertation, Northeast Normal University, Changchun. (in Chinese with English abstract) [王振海 (2016) 长白山针 叶林调落物分解及土壤动物在调落物分解和元素释放中 的作用. 博士学位论文, 东北师范大学, 长春.]

Wang ZH, Yin XQ, Li XQ (2015) Soil mesofauna effects on litter decomposition in the coniferous forest of the Changbai Mountains, China. Applied Soil Ecology, 92, 64-71.

Xin WD, Yin XQ, Qin LJ, Chen YB, Zhang XP, Chen P (2009) Ecogeographical distribution characteristic of soil mesofauna in forest ecosystem of Xiao Hinggan Mountains. Scientia Geographica Sinica, 29, 129-133. (in Chinese with English abstract) [辛未冬, 殷秀琴, 秦丽杰, 陈颖彪, 张雪 萍, 陈鹏 (2009) 小兴安岭森林生态系统中小型土壤动 物生态地理分布特征. 地理科学, 29, 129-133.]

Yin XQ, Jiang YF, Tao Y, An JC, Xin WD (2011) Ecogeographical distribution of soil fauna in Pinus koraiensis mixed broad-leaved forest of Changbai Mountains. Scientia Geographica Sinica, 31, 935-940. (in Chinese with English abstract) [殷秀琴, 蒋云峰, 陶岩, 安静超, 辛未冬 (2011) 长白山红松阔叶混交林土壤动物生态分布. 地理科学, 31, 935-940.]

Yin XQ, Li JX, Dong WH (2007c) Microelement contents of litter, soil fauna and soil in Pinus koraiensis and broadleaved mixed forest. Chinese Journal of Applied Ecology, 18, 277-282. (in Chinese with English abstract) [殷秀琴, 李金霞, 董炜华 (2007c) 红松阔叶混交林调落叶、土壤动 物、土壤的微量元素含量. 应用生态学报, 18, 277-282.]

Yin XQ, Liu JL, Gao M (2007a) Relationships of nutrient elements in forest ecosystem of Xiao Hinggan Mountains and role of soil fauna. Scientia Geographica Sinica, 27, 814-819. (in Chinese with English abstract) [殷秀琴, 刘继亮, 高明 (2007a) 小兴安岭森林生态系统中营养元素关系及土壤 动物的作用. 地理科学, 27, 814-819.]

Yin XQ, Qiu LL, Jiang YF, Wang YQ (2017) Diversity and spatial-temporal distribution of soil macrofauna communities along elevation in the Changbai Mountain, China. Commu- 
nity and Ecosystem Ecology, 46, 454-459.

Yin XQ, Qiu LL, Yang LB, Song B (2006) The relation and difference of nutritional elements in forest litter-macrofaunassoil system. Geographical Research, 25, 320-326. (in Chinese with English abstract) [殷秀琴, 邱丽丽, 杨令宾, 宋 博 (2006) 森林调落物-土壤动物-土壤系统中营养元素 含量关系及分异. 地理研究, 25, 320-326.]

Yin XQ, Song B, Dong WH, Xin WD, Wang YQ (2010) A review on the ecogeography of soil fauna in China. Journal of Geographical Sciences, 20, 333-346.

Yin XQ, Song B, Qiu LL (2007b) Dynamic characteristics of $\mathrm{N}, \mathrm{P}, \mathrm{K}$ in the litter-soil fauna-soil system of mixed Pinus koraiensis and broad-leaved forest. Acta Ecologica Sinica, 27, 128-134. (in Chinese with English abstract) [殷秀琴, 宋博, 邱丽丽 (2007b) 红松阔叶混交林调落物-土壤动 物-土壤系统中 $N 、 P 、 K$ 的动态特征. 生态学报, 27 , 128-134.]

Yin XQ, Xue WL, Ma C (2016) Diversity and ecological geographic distribution of soil fauna in basalt platform of the Changbai Mountains, China. Scientia Geographica Sinica, 36, 1106-1114. (in Chinese with English abstract) [殷秀琴, 薛文丽, 马辰 (2016) 长白山玄武岩台地土壤动物多样 性及其生态地理分布. 地理科学, 36, 1106-1114.]

Yin XQ, Zhang GR (1993) Correlation between forest litter and soil macroanimals. Chinese Journal of Applied Ecology, 4, 167-173. (in Chinese with English abstract) [殷秀琴, 张桂 荣 (1993) 森林调落物与大型土壤动物相关关系研究. 应用生态学报, 4, 167-173.]

Yin XQ, Zhao HY (1994) A study of the composition and distribution of soil animals in the southern Songnen Plain grassland. Acta Prataculturae Sinica, 3, 62-70. (in Chinese with English abstract) [殷秀琴, 赵红音 (1994) 松嫩平原 南部土壤动物组成与分布研究. 草业学报, 3, 62-70.]

Yin XQ, Zhong WY, Wang HX, Chen P (2002) Decomposition of forest defoliation and role of soil animals in Xiao Hinggan Mountains. Geographical Research, 21, 689-699. (in Chinese with English abstract) [殷秀琴, 仲伟彦, 王海霞, 陈鹏 (2002) 小兴安岭森林落叶分解与土壤动物的作用. 地理研究, 21, 689-699.]

Zhang LM, Meng LJ, Guo CW, Gao MX, Liu D, Zhang XP (2015) Spatial heterogeneity of soil mite community and its spatial relationship with environmental factors in Maoer Mountains. International Journal of Smart Home, 9, 141-148.

Zhang M, Liang WJ, Zhang XK (2012) Soil nematode abundance and diversity in different forest types at Changbai Mountain, China. Zoological Studies, 51, 619-626.

Zhang RZ, Yang MX, Chen P, Zhang TW (1980) Preliminary investigation on soil animals in ecosystem on the northern slope of Changbai Mountain. Forest Ecosystem Research, I, 133-152. (in Chinese with English abstract) [张荣祖, 杨明 宪, 陈鹏, 张庭伟 (1980) 长白山北坡生态系统土壤动物 初步调查. 森林生态系统研究, I, 133-152.]

Zhang W, Zhang XP (2013) Soil macrofauna community diversity of different tundra in Da Hinggan Mountain. Journal of Northeast Forestry University, 41, 124-126, 157. (in Chinese with English abstract) [张武, 张雪萍 (2013) 大兴 安岭不同冻土带大型土壤动物群落样性. 东北林业大学 学报, 41, 124-126, 157.]

Zhang XK, Guan PT, Wang YL, Li Q, Zhang SX, Zhang ZY, Bezemer TM, Liang WJ (2015) Community composition, diversity and metabolic footprints of soil nematodes in differently-aged temperate forests. Soil Biology \& Biochemistry, 80, 118-126.

Zhang XP, Cao HC, Feng ZK (2007) Ecological and geographical study on small and middle sized soil animals in Da Hinggan Mountains, northeastern China. Journal of Beijing Forestry University, 29, 259-265. (in Chinese with English abstract) [张雪萍, 曹会聪, 冯仲科 (2007) 大兴安岭森林 生态系统中小型土壤动物生态地理特征分析. 北京林业 大学学报, 29, 259-265.]

Zhang XP, Huang LR, Jiang LQ (2008) Characteristics of macro-soil fauna in forest ecosystem of northern Da Hinggan Mountains. Geographical Research, 27, 509-518. (in Chinese with English abstract) [张雪萍, 黄丽荣, 姜丽秋 (2008) 大兴安岭北部森林生态系统大型土壤动物群落特 征. 地理研究, 27, 509-518.]

Zhang XP, Li ZH, Yin XQ (1996) The composition and ecological distribution of soil animals in larch plantation. Journal of Jilin Forestry University, 12, 164-168. (in Chinese with English abstract) [张雪萍，李振会，殷秀琴 (1996) 落叶松人工林土壤动物组成与分布. 吉林林学院学报, 12, 164-168.]

Zhang Y, Chen P (1984) The main soil types and the soil animals of mountainous region, east of Jilin Province. Journal of Northeast Normal University, (2), 83-92. (in Chinese with English abstract) [张一, 陈鹏 (1984) 吉林省东部山 地主要土壤类型及土壤动物. 东北师大学报自然科学版, (2), 83-92.]

Zhong WY, Yin XQ, Chen P (1999) Relationship of litter decomposition and consumption with soil animals in Maoer Mountain forest. Chinese Journal of Applied Ecology, 10, 128-129. (in Chinese with English abstract) [仲伟彦, 殷秀 琴, 陈鹏 (1999) 帽儿山森林落叶分解消耗与土壤动物 关系的研究. 应用生态学报, 10, 128-129.]

(责任编委：傅声雷 责任编辑: 时意专) 